\title{
LEADERSHIP BY THE CURRICULAR DEPARTMENT COORDINATOR: TEACHERS' PERCEPTIONS
}

\author{
S. Catarino ${ }^{1}$, M. Abelha ${ }^{2}$, C. Costa-Lobo ${ }^{3}$, F. Seabra ${ }^{4}$ \\ ${ }^{1}$ Escola Secundária Dr. Serafim Leite e INPP, Universidade Portucalense (PORTUGAL) \\ ${ }^{2}$ INPP, Universidade Portucalense e CEIS20, Universidade de Coimbra (PORTUGAL) \\ ${ }^{3}$ INPP, Universidade Portucalense (PORTUGAL) \\ ${ }^{4}$ LE@D, Universidade Aberta e CIEd, Universidade do Minho (PORTUGAL)
}

\begin{abstract}
The aim of this paper is to present a case study carried out in two clusters of schools in the metropolitan area of Oporto, Portugal. The study reflects upon the teachers' perceptions about the coordinator as the "leader" of the curricular department, based on the problem: "What are the contributions of the coordinator's leadership for the dynamics of teaching, developed in the curricular department?"

The following aims were defined: to analyze the role and functions of the coordinator of the curricular department from the perspective of the legal diplomas; to understand the coordinator's perception concerning job accomplishment; to understand which practices are adopted by the coordinator concerning their curricular department in its daily action; to understand teachers' perceptions with regard to the exercise of the coordinator's tasks; to understand the coordinator's influence upon teacher's teaching practices; to identify features that teachers consider important to acknowledge the department coordinator as a leader.

To accomplish this, a qualitative approach has been used, similar to a case study, using techniques such as surveys and interviews. The framework initially focused on an analysis of the framework at the level of legislative regulations, essentially, as they regard the position of curricular department coordinator and / or similar; later approaching the concepts of leadership, through a brief history about the theories of leadership.

Based on the analysis of teachers' opinions about the functions and influence of the coordinator, namely representation, communication, interaction, collaboration, promotion of personal initiative, problem solving and common objectives, the results point towards teachers' perceptions being mainly oriented to coordinator with a predominantly transformational leadership.
\end{abstract}

Keywords: Coordinator, Curricular Department, Leadership.

\section{INTRODUCTION}

If school organization is conceived as simply maintaining order, perpetuating procedures, complying with routine to achieve what is defined by some, management is enough. However, considering that today nothing is immutable, that new situations and new challenges are always emerging, that those who make a difference are people as individuals or as constituent elements of a collective organization, leadership may be the answer we seek ${ }^{[1]}$. In this sense, leadership in educational organizations has been pointed out by several investigations ${ }^{[2],[3],[4],[5],[6],[7]}$ as a fundamental factor for the improvement of schools and, consequently, improvement of the teaching and learning processes. In this regard, Sergiovanni ${ }^{[8]}$ warns that "our ability to improve schools depends on our ability to create unique leadership for school organization. We can not have one without having the other ".

Portuguese schools are generally organized according to curricular departments, which are structures for educational coordination and pedagogical supervision, which ensure articulation and curricular management through the development and management of study plans and programs defined at the national level and of local components of curricula, in conjunction with the School's Educational Project. The curricular departments are organized in disciplinary areas or pedagogical teams.

With the changes introduced by Portuguese legal norms, the curricular departments are becoming especially important in the development of the work dynamics of the schools and their coordinators are entrusted with this responsibility, as intermediary managers of the whole process. According to Oliveira ${ }^{[9]}$, an intermediate manager can be defined as: "an educational actor who, because of his 
position in the context of the school community, has the possibility to recognize the imbalances and dysfunctions of the school system and has the autonomy and legitimacy to promote measures of support and correction, aimed at improving the performance of teachers, with the ultimate purpose of promoting educational success".

According to the Portuguese legislation, it is the responsibility of the department coordinator, among other functions, to promote the exchange of experiences and cooperation between teachers; the coordination of curriculum guidelines and curricula; to promote articulation with other structures and carry out research, reflection and study activities with the aim of improving the quality of educational practices; to propose the adoption of measures to improve student learning; to collaborate in the elaboration, development and evaluation of the autonomy instruments and to present an annual critical report.

Until 2007 the coordinators were elected by the teachers who belonged to the department. However, with the enactment of the Decree-Law $15 / 2007^{[10]}$, the department coordinators are no longer elected by their peers, but rather nominated by the director. However, in 2012, the selection of the coordinator of the curricular department returned to election by the peers, although it is conditioned by the proposal of the school director based on some requirements defined by law (Article 43, paragraph 5 , Decree-Law $137 / 2012^{[11]}$ ), in particular, the department coordinator should, whenever possible, be a career teacher with specialized training in the areas of pedagogical supervision, teacher performance evaluation or educational administration. The duration of this position lasts for four years.

Because of the role and functions that the curricular department coordinator is called upon to play, leadership is an essential tool for this position, as well as the ability to work collaboratively, because if the coordinator is not capable of involving and committing all teachers with common goals, they will find it very hard to succeed in the fulfillment of their duties. In this sense, the protagonism of these actors is increased by the importance they have in the school organization and by the mechanisms that are adopted for their accountability in the process of autonomy and management of the schools, since this is considered an intermediate management position that requires effective leadership.

Leadership is a polysemous concept that over time has assumed different theoretical interpretations, however when those interpretations are considered as a whole, it is possible deduce that leadership is seen as a relation of influence exerted within a group, with a well-defined intention ${ }^{[12]}$. There are thus two common aspects to definitions which are: i) that it is a group phenomenon and ii) that it involves influence.

A precondition of this research is that leadership at a school context is not a neutral field, easily manipulated by any technocratic take-away recipe ${ }^{[13]}$, but that it translates into a dynamic, socially constructed process of influence leading to the implementation of the plan of action decided and defended by the leadership team elected by their peers. However, effective leaders share with other educational actors a strategic vision based on values, in the sense of the work projects to be carried out, corresponding to the realization of this strategic vision and, ultimately, to the implementation of the action plan outlined ${ }^{[14]}$.

The curriculum coordinator as an intermediate management leader can adopt several styles / behaviors for the leadership of the curricular department, namely: transformational, transactional and laissez-faire.

Transformational leadership has assumed an increasing importance, since a transformational leader is someone who not only motivates his followers, but also stimulates changes in their attitudes in order to stimulate them to pursue common objectives ${ }^{[15]}$. This type of leadership is characterized by four components:

1 inspirational, which promotes motivation, the definition of goals and objectives;

2 charismatic, which stimulates the development of a common vision and instills pride, respect and trust;

3 the respect by those they are responsible for, giving them all the attention and support necessary for them to develop professionally and achieve not only the organizational goals, but also their own individual objectives and

4 intellectual stimulation - towards to challenge people under their direction to reach new goals, overcoming their limits in the search for creative solutions that allow the resolution of the diagnosed problems. 
Transformational leadership is ultimately moral since it elevates the level of human conduct and the moral aspiration of both the leader and the led, resulting in a transformation for the better in both. With respect to transactional leadership, this focuses on the attribution of a system of rewards and punishments to be applied by the leader as a result of the fulfillment or non-fulfillment of the predefined objectives. In transactional leadership, the leader only points out which behaviors his subordinates must adopt and which goals to achieve, not influencing or motivating their followers to pursue the desired goals ${ }^{[15]}$.

According to Robbins ${ }^{[16]}$, transactional and transformational leadership are two complementary models, since "transformational leadership is built upon transactional leadership - it produces, in the led, levels of effort and performance that go beyond transactional approach" ${ }^{[1]}$. As far as laissez-faire leaders are concerned, they are characterized by the weak or even non-existent exercise of the leader's role within the organization, because they avoid making decisions and abdicate their responsibility and authority.

In the last decade the role of the coordinator of curricular department has been gaining a central role in the panorama of pedagogical guidance in Portuguese schools. In addition to the responsibility to coordinate, supervise and evaluate teachers, the coordinator's action extends to the development of a leadership that promotes the creation of new dynamics of collaborative teaching work.

Based on a research carried out within the Master's Degree in Administration and Management of Education, at the University Portucalense Infante D. Henrique (Portugal), the need arose to deepen knowledge not only about coordinator's functions and perceptions about their daily practices, but also, the perceptions of teachers who integrate the various curricular departments about the functions and practices of their coordinators; and to identify aspects of leadership recognized as characteristic of department coordinators, by their peers.

\section{METHODOLOGY}

In the present study, the research problem is in the analysis and understanding of leaderships in school context, specifically those of the department coordinator and it is translated into the following question: What are the contributions of the coordinator's leadership for the dynamics of teaching, developed in the curricular department?

To produce knowledge about this research problem, the following research objectives were established:

1 to analyze the role and functions of the coordinator of the curricular department from the perspective of the legal diplomas;

2 to understand the coordinator's perception concerning job accomplishment;

3 to understand which practices are adopted by the coordinator concerning their curricular department in its daily action;

4 to understand teachers' perceptions with regard to the exercise of the coordinator's tasks;

5 to understand the coordinator's influence on teacher's teaching practices;

6 to identify features that teachers consider important to acknowledge the department coordinator as a leader.

Bearing in mind that the purposes of this study lie within the scope of the understanding of the studied phenomenon - leaderships - within its context - the curricular department - we have chosen an essentially qualitative methodology - case study - because it allows us to understand the meaning that the participants attribute to their experiences ${ }^{177}$. In this sense, the present study was carried out in two clusters of schools that have a consolidated public image in the educational community and in the surrounding environment, both integrating the Porto Metropolitan Area (Portugal).

In order to guarantee the confidentiality and anonymity to the participating teachers, we will designate the clusters as East and West and have chosen to collect data through a questionnaire survey applied to 219 teachers of the two selected clusters of schools, and through a semi-structured interview conducted to eight coordinators of the different departments that structure the clusters of schools under study.

Considering the quantitative and qualitative nature of the information collected, chosen data processing techniques were: the statistical analysis, to treat the data resulting from the questionnaire 
survey; and content analysis to handle the data resulting from the interviewees' statements and the school internal documents analysed. A comparative analysis was also performed, by triangulation between the results obtained by the questionnaires applied to teachers and the results obtained by the interviews conducted to the coordinators of the curricular departments.

\section{RESULTS}

In this section, the results obtained through interviews to eight coordinators of the curricular departments and the questionnaires applied to the 219 teachers are presented and are discussed. The empirical study was carried out in the school year 2012/2013 in two clusters of schools (CS) organizational units, with their own administrative and management bodies, consisting of pre-school education establishments and one or more levels and cycles of teaching, with a common educational project - located in the Metropolitan area of Porto. Both the head schools of each of the CS have been in existence since the middle of the last century, enjoying equal recognition in the environment in which they are inserted and both were intervened in the scope of the requalification of the school park.

Table 1. Characterization of school clusters.

\begin{tabular}{|c|c|c|c|c|c|c|c|c|c|}
\hline \multirow[t]{2}{*}{ CS } & \multirow{2}{*}{$\begin{array}{c}\text { No. of } \\
\text { departments }\end{array}$} & \multicolumn{2}{|c|}{ No. of teachers } & \multirow{2}{*}{$\begin{array}{c}\text { No. of } \\
\text { questionnaires }\end{array}$} & \multirow[t]{2}{*}{ Sample } & \multirow{2}{*}{$\begin{array}{c}\text { No. of } \\
\text { students }\end{array}$} & \multirow{2}{*}{$\begin{array}{l}\mathrm{N}^{\circ} \text { of classes } \\
\text { of the } 2 \mathrm{nd} \\
\text { cycle }\end{array}$} & \multirow{2}{*}{$\begin{array}{c}\mathrm{N}^{\circ} \text { of classes } \\
\text { of the } 3 \mathrm{rd} \\
\text { cycle }\end{array}$} & \multirow{2}{*}{$\begin{array}{l}\text { Number of } \\
\text { classes } \\
\text { secondary }\end{array}$} \\
\hline & & Female & Male & & & & & & \\
\hline East & 4 & 172 & 38 & $\begin{array}{c}158 \\
(15 \text { not } \\
\text { validated })\end{array}$ & $91 \%$ & 2031 & 29 & 25 & 28 \\
\hline West & 4 & 129 & 55 & $\begin{array}{c}82 \\
(6 \text { not } \\
\text { validated })\end{array}$ & $41,3 \%$ & 2027 & 12 & 36 & 40 \\
\hline
\end{tabular}

The organizational structure of each of the CSs is similar, each with four curricular departments (CD), namely: the Social and Human Sciences, made up of teachers from the disciplines of History, Geography, Philosophy and Economy; Mathematics and Experimental Sciences, made up of teachers of Mathematics, Natural Sciences, Physics and Chemistry, Biology and Geology and Informatics; the Expressions, made up of teachers of the disciplines of Physical Education, Special Education, Visual Education, Music Education, Technological Education and Visual Arts; and that of Languages made up of teachers of Portuguese, English, French and Spanish subjects.

In both CSs the role of coordinator of curricular department (CCD) is played by teachers with a minimum of twenty-five years of teaching, of which at least eighteen years were spent in the school where they are currently. Whereas in the West CS all four CCDs have specific training for the position, in the East CS none of the CCDs have any specific training. Most teachers in both CS teach at two different levels of teaching as well as hold a position other than CCD. With the exception of two CCDs who have been in that position for one and two years, every other CCD has more than six years of experience in performing those duties.

There are similarities between CCDs of both CS at the levels of: age, total length of service, length of service in the current school, performance of other positions in the present, and experience in the performance of positions. The differences among CS are related to the complementary training and the amount of teaching levels taught in the school year under analysis.

During the academic year of 2012/2013, 219 teachers participated in the study, both from the East CS $(65.3 \%)$ and West CS $(34.7 \%)$. The average age of respondents from the West CS is 47 years old and in the East CS it is 45 years old. As far as academic qualification is concerned, the majority of respondent teachers are graduates and a third hold postgraduate degrees; It is noteworthy that among the whole sample only one teacher is a $\mathrm{PhD}$, in the area of sport.

The CCD of both CSs when asked about the strengths of the school where they teach, recognize the importance to leadership, faculty, and collaborative work. All CCDs identify deeply with the school, and enjoy the work environment of their CS. In relation to the less positive aspects, aspects resulting from the national context, the political decisions taken and the attitude of certain individual teachers were identified. 
From the analysis carried out on CCD perceptions about the school where they work, the recognition of leadership $(50 \%)$ is a strong point in both groups, which can contribute to "improve schools" ${ }^{[8]}$ and for the creation of schools "where it is good to study, teach and work" ${ }^{[18]}$. In this respect, the studies point to the importance of a strong leadership to the dynamics of organizations, through guidance, motivation, adaptation to situations, emphasizing efforts and promoting group cohesion, among others. That proximity and co-operation with management, as top leadership in school organizations, is critical to cementing middle-level leadership [19], [15], [20], [21].

Regarding the feelings that existed at the beginning of the performance of the position of CCD, spontaneity $(37 \%)$, anxiety $(25 \%)$; fear $(25 \%)$ and anger $(12.5 \%)$ were mentioned. Currently, CCD's feelings tend towards spontaneity $(50 \%)$, tranquillity $(25 \%)$, fear $(12.5 \%)$ and discomfort $(12.5 \%)$. All the CCDs involved in the study state that there have been contributions to their professional development, especially at the level of enrichment $(37 \%)$ and at the level of perception of the school as a whole $(37 \%)$. The sense of recognition towards the work developed is perceived by most CCD $(87 \%)$.

Regarding teachers' perceptions regarding the performance of the CCD functions, through an analysis of the questionnaire items, half of the respondents from both CSs fully agree that the CCD represents the department and is informed about the dynamics of the school. The CCD also supports this view, in particular, by the involvement (75\%) and contributions to the dynamics of the school (82.5\%).

With regard to communication with the department, most teachers in both CSs fully agree the CCD conveys decisions clearly and shares relevant information, however, in East CS $45.5 \%$ agree that the CCD listens to opinions, whereas in West CS, the majority of teachers $(67.1 \%)$ fully agree with that assertion.

In the scope of interaction, half of the teachers of both CS disagree completely $(50.2 \%)$ that the CCD is unavailable when requested by the teachers and in the same sense this is perceived by the CCD that affirm their availability as essential for the exercise of their duties. The availability of the coordinators when requested is one of the factors that allow us to gauge the extent to which interaction takes place, since we consider that if the coordinator is not available, they cannot perform their tasks of guiding the teachers in the desired direction. ${ }^{[13], ~[21]}$

In the perception of $45.2 \%$ of the respondent teachers, the CCD strongly encourages the participation of all in search for a joint decision, agreeing that this is verified through the encouragement of collaborative work, the promotion of curricular articulation and the fostering of articulation between departments. Collaboration between CCD and faculty should be the main form of work in departments and effectively the promotion of this work is recognized by faculty in all departments. Attention is drawn to the fact that, in the perception of the department coordinators, the coordination of a large number of teachers with diverse backgrounds (62.5\%) is one of the most difficult tasks to implement; In that sense one of the options found to stimulate, foster and promote collaboration is to do so in small to medium groups.

With regard to the encouragement and support of teachers' projects / initiatives, $47.6 \%$ of the teachers of the East CS agree that the CCD performs this function, in turn, in the West CS the opinions of the majority of the teachers are divided among those who agree and those who agree completely, both with $44.7 \%$. In both CSs the majority of respondents (42\%) agree that the CCD incentivizes teachers to reach the objectives they propose. $43,4 \%$ of respondents from East CS agree and the same percentage of respondents from West CS fully agree that the CCD incentivizes teachers to improve their professional activity. Several CCD express positions that support these positions, as they consider they promote and incentivize the teachers to participate in departmental activities such as exhibitions, study visits, clubs.

Regarding problem solving, $27.4 \%$ of teachers responding to both CSs disagree strongly that the CCD avoids making decisions and $42 \%$ agree that the CCD demonstrates effectiveness in meeting the needs of others in relation to work. One of the reasons that may explain this perception may be in what is said by one of the CCD when stating that "we have more tasks, not only the time we spend in school to do things it is the diversity of things we do .... and therefore .... We do not have the ability to properly focus on important tasks", yet $62.5 \%$ of CCD try to respond / help / support requests.

The majority (59.4\%) of teachers from both CS totally agree that the CCD conducts meeting efficiently, and $45.7 \%$ fully agree they promote the department's efficiency. Concerning the teachers' perception of the influence of the CCD on the dynamics of teaching work in the department, $50.7 \%$ of respondents from both CSs fully agree that the CCD represents the department before the Director 
effectively. The way in which the CCD represents the department interferes with the way they are perceived by teachers and the feedback they are given. If teachers recognize that the department is effectively represented it is likely that they will also want to make departmental action effective. In this way we are convinced that the example that the CCD gives when representing and defending the interests of the department works as a driving force for the achievement of the defined objectives, by the teachers.

Regarding the promotion of communication among teachers, in the East CS $44.8 \%$ of respondent teachers agree that it exists; In the West CS 51.3\% fully agree. Concerning the CCD's demonstration of openness to suggestions presented by teachers, the majority of respondents from both groups of teachers $(52.5 \%)$ agree totally. Most teachers in both groups (47.5\%) agree the CCD communicates what needs to be done with enthusiasm. There are statistically significant differences between groups perceptions regarding the promotion of communication between teachers and openness to suggestions made by teachers, but there are no statistically significant differences concerning communication with enthusiasm about what needs to be done.

Regarding the encouragement by the CCD of good relationships among all the teachers, in the East CS $42.7 \%$ agree, and in the West CS, $60.5 \%$ totally agree. In the East CS $42.7 \%$ of respondent teachers agreed and in the West CS $60.5 \%$ agreed the CCD's daily professional performance is coherent. Regarding the provision of a good working environment by the CCD, the majority of teachers from both CS (52.1\%) completely agree. Interaction, coupled with communication, is another of the actions that the CCD have the obligation to promote since a relationship based on trust in addition to causing change, makes the group more cohesive ${ }^{[20],[22]}$. If teachers feel comfortable in their environment and what they observe in the leader, we believe that they become more committed, responsible, and active. ${ }^{[1],[23]}$

Regarding the promotion of planning opportunities among groups and / or disciplines, most respondent teachers from both CS (45\%) agree that the CCD promotes such opportunities. Regarding the CCD working with others satisfactorily, in the East CS $42.7 \%$ of the teachers respondents agree and in the West CS $51.3 \%$ of the teachers totally agree. With regard to the CCD's encouragement of the involvement of teachers in school activities, in the East CS $46.9 \%$ of teachers agree, and in the West CS, $44.7 \%$ totally agree.

For $15.5 \%$ of respondent teachers the CCD does not promote opportunities for planning, articulation and joint work among teachers from different groups / disciplines. Providing moments in which this may happen is the responsibility of the department coordinator, but in their opinion this happens, essentially within a group. On the one hand, because three or four department meetings per year are not enough, and on the other because the variety of disciplines in each department and the high number of teachers in each department is not conducive to this happening, which also meets Lima's ${ }^{[24]}$ opinion when he states that there is "rare exchange of experiences among colleagues who teach different disciplines". However, in the perception of most of the teachers at the various departments, articulation is promoted, so it is probable that this perception is directly related to the work at the level of each group / discipline. Disciplinary groups often meet to analyse, reflect, adapt, prepare, share, carry out and evaluate the most varied aspects of school dynamics in their curricular and extracurricular practice.

Regarding the development of leadership strategies (cooperation, delegation of responsibilities, etc.) by the CCD, $42 \%$ of the teachers in both CSs agree that it takes place. In the context of encouraging teachers to work with greater dedication on the part of the coordinator, most of the teachers in both groups agree that the CCD encourages them. Allowing others to act, encouraging initiative, stimulating creativity and delegating responsibilities are some of the actions that the CCD must take to promote proactive action by the departmental teachers ${ }^{[1],[15],[22]}$. This attitude takes into account the individual needs, the will of each one to feel accepted, integrated and supported, leading to intrinsic motivation and pleasure in what is accomplished and achieved. The promotion of this feeling adds value to the effectiveness of school and educational action, because it leads teachers to act beyond their personal interests. ${ }^{[8]}$

Regarding the CCD considering different perspectives to solve problems, in the East CS $46.2 \%$ of the respondent teachers agree and in the West CS $46.1 \%$ totally agree. Regarding the delay in responding to urgent questions by the coordinator, in both CSs, $37.9 \%$ of teachers disagree completely and there is a percentage of $20.1 \%$ of teachers who neither agree nor disagree. The perception that some teachers have about the delay of the CCD in responding to urgent questions may be related to the coordinators' perception about the quantity and variety of tasks that are 
requested of them in function of the time that they have for the exercise of the functions. Listening to everyone's opinion, considering different ways of thinking, acting and reacting, as well as being quick to promote the necessary action, not only for teachers to feel that their needs are being met but also to feel motivated to acting appropriately, is critical to the dynamics of the department. ${ }^{[13],[19]}$

Regarding the promotion of the importance of common objectives among teachers, $49.3 \%$ of teachers in both CS agree that the CCD is concerned with it. In the context of the prevalence of group interests to the detriment of the CCD personal interests, the opinion of $39.2 \%$ of the responding teachers from both CS agree; it is worth noting that in the East CS there are $30.7 \%$ of teachers who do not agree or disagree and in the West CS there is a relevant percentage of teachers $(35.5 \%)$ who fully agree, such teachers' perceptions may be related to lack of knowledge of the time invested by the CDC in the performance of their tasks.

Regarding the characteristics of leadership, the respondent teachers listed as more important: communication capacity $(70 \%)$; professional competence $(65.8 \%)$ and problem-solving ability $(63.9 \%)$. The leadership characteristic considered as less important was the antiquity $(87.7 \%)$, which is understandable, since, there are no current studies that prove that the age or time of service of an individual translate into greater and / or better leadership skills.

\section{CONCLUSIONS}

Given the results obtained and taking into account the research objectives outlined, we can conclude that the CCD has been gaining prominence as an intermediate management leader, being responsible for the dynamization of the department as a whole. In the CCD's own account, their motivations to perform this role are related to the belief that they can make a difference in the dynamics of the teaching work. They relate that they feel recognized for what they do, feel comfortable in performing their duties and are enriched professionally. They consider that they promote reflection and collaborative work among teachers who belong to the same disciplinary group. Lack of time, as well as the variety of tasks performed, the management of different groups and the high number of teachers that make up the department are the main constraints to the exercise of the position of CCD.

Concerning the teachers' perceptions regarding the exercise of the CCD functions and their influence on the dynamics of teaching work, the opinions of a significant number of teachers at both CS is that the CCD: i) represents the department at hierarchically superior levels; ii) has communication skills and promotes communication among all; iii) is available to requests; iv) stimulates the good relationship between teachers, promoting a good work environment; v) promotes collaborative work, essentially at the level of each disciplinary group; vi) encourages projects / actions of the teachers' initiative; vii) encourages the improvement of teachers' professional action; (viii) acts in the face of problems and is quick to respond to urgent issues; and ix) shares common goals with teachers.

As far as the research problem is concerned, it is possible to conclude that in the teachers' perception the CCD as a leader to the department contributes to the dynamics of work among teachers through the sharing of common objectives and collaborative work, based on an interaction that takes into account the needs of each one, helping to solve the problems that arise and encouraging / promoting personal and collective initiative, through their availability and support, directing and "feeding" that will through their ability to communicate. In this context it is worth mentioning that the coordinator cannot forget that people are the most important factor of any organization and that in their leadership action must strengthen the power of people taking advantage of their physical, mental, social, emotional and spiritual capacities, through perseverance, credibility, discipline and intelligence on their part. ${ }^{[25]}$

\section{REFERENCES}

[1] Rego, A. \& Cunha, M.P., "A essência da liderança”, Lisboa: Editora RH, 2003.

[2] Bolívar, A., "Como melhorar as escolas. Estratégias e dinâmicas da melhoria das práticas educativas", Porto: Editora Asa, 2003.

[3] Covey, S. R., "A terceira alternativa. Estratégias e soluções para resolver os problemas mais difíceis da vida”, Lisboa: Gestão Plus Editora, 2012.

[4] Day, C. et al., "Research into the impact of school leadership on pupil outcomes: Policy and research contexts", School leadership \& management: formerly school organisation, v. 28, n. 1, p. 5-25, 2008. 
[5] Fullan, M., "Liderar numa cultura de mudança", Porto: Editora Asa, 2003.

[6] Glanz, J., "À descoberta do seu estilo de liderança. Um guia para educadores e professores", Porto: Editora Asa, 2003.

[7] Pashiardis, P. (Ed.), "Modeling School Leadership Across Europe. In search of new frontiers", Dordrecht: Springer, 2014.

[8] Sergiovanni, T. J., "Novos caminhos para a liderança escolar”, Porto: Edições ASA, 2004.

[9] Oliveira, M., "O papel do gestor pedagógico intermédio na supervisão escolar" in "Escola reflexiva e supervisão. Uma escola em desenvolvimento e aprendizagem” (Alarcão org.), Porto: Porto Editora, 2001.

[10] Decreto - Lei no 15/2007 de 19 de janeiro, "Diário da República $n^{\circ} 14,1^{a}$ Série", Ministério da Educação, Lisboa, 2007.

[11] Decreto - Lei no 137/2012 de 2 de julho, "Diário da República $n^{\circ} 126,1^{a}$ Série", Ministério da Educação, Lisboa, 2012.

[12] Costa, J. A., "Gestão e formação de lideranças na educação", $19^{\circ}$ Congresso Internacional EDUCAR/EDUCADOR, Brasil: São Paulo, 16 a 19 de Maio de 2012. Disponível: http://www.futuroeventos.com.br/arquivo_eventos/educar/Jorge-AdelinoCosta_management.pdf. Acesso: Fevereiro 2013.

[13] Costa, J. A., "Lideranças nas organizações: revisitando teorias organizacionais num olhar cruzado sobre as escolas", in "Liderança e estratégia nas organizações escolares" (J. A. Costa; A. Neto-Mendes \& A. Ventura Orgs.), Atas do I Simpósio sobre organização e gestão escolar, pp.15-33, Portugal: Universidade de Aveiro, 2000.

[14] Abelha, M. C. L, "Trabalho colaborativo docente na gestão do currículo do Ensino Básico: do discurso às práticas", Tese (Doutoramento em Didática) — Universidade de Aveiro, Aveiro, 2011.

[15] Castanheira, P. \& Costa, J., "Lideranças transformacional, transaccional e laissez-faire: um estudo exploratório sobre os gestores escolares com base no MLQ" in "A Escola sob suspeita", (J. Sousa \& C. Fino Orgs.), pp. 141-154, Porto: Edições Asa, 2007.

[16] Robbins, S., "Comportamento organizacional", São Paulo: Prentice Hall, 2002.

[17] Yin, R., "Estudo de Caso: Planejamento e Métodos", 3ª ed.,Porto Alegre: Bookman, 2005.

[18] Alarcão, I. \& Tavares, J., "Supervisão da prática pedagógica. Uma perspetiva de desenvolvimento e aprendizagem”, $2^{\mathrm{a}}$ ed., Coimbra: Almedina, 2003.

[19] Bilhim, J. A. F., "Teoria Organizacional: Estruturas e Pessoas", $5^{a}$ ed., Lisboa: Instituto Superior de Ciências Sociais e Políticas, 2006.

[20] Gomes, A. R., \& Cruz, J., "Abordagem carismática e transformacional: modelos conceptuais e contributos para o exercício da liderança”, Psicologia USP, 18 (3), pp.143-161, Brasil: São Paulo, jul./set 2007, Disponível: http://hdl.handle.net/1822/7779, Acesso: junho 2013.

[21] Silva, J. M., "Líderes e lideranças em escolas portuguesas: protagonistas, práticas e impactos", Vila Nova de Gaia: Fundação Manuel Leão, 2010.

[22] Kouzes, J. M. \& Posner, B. Z., "O desafio da Liderança”, 3a ed., Brasil: Rio de Janeiro: Editora Campus, 2003.

[23] Bento, A. V., "Os estilos de liderança dos líderes escolares da Região Autónoma da Madeira", in "Atas do V Simpósio sobre Organização e Gestão Escolar - Trabalho Docente e Organizações Educativas" (J. A. Costa, A. Neto-Mendes, \& A. Ventura Org.), pp.145-157, Portugal: Universidade de Aveiro, 2008, Disponível: http://hdl.handle.net/10400.13/55. Acesso: março 2013.

[24] Lima, J.A., "Lideranças nas organizações: revisitando teorias organizacionais num olhar cruzado sobre as escolas", in "Liderança e estratégia nas organizações escolares", (J. A. Costa; A. Neto-Mendes \& A. Ventura Orgs.), Atas do I Simpósio sobre organização e gestão escolar, pp.65-93, Portugal: Universidade de Aveiro, 2000. 


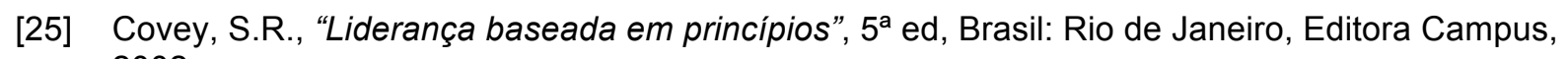
2002. 